\title{
Cold Acclimation and Alterations in Protein Synthesis in Bermudagrass Crowns
}

\author{
Mark J. Gatschet ${ }^{1}$, Charles M. Taliaferro ${ }^{1}$, Jeffrey A. Anderson ${ }^{2}$, David R. Porter ${ }^{3}$, \\ and Michael P. Anderson ${ }^{1}$ \\ Oklahoma State University, Stillwater, OK 74078
}

Additional index words. cold hardening, cold-regulated proteins, Cynodon dactylon $\mathrm{x}$ C. transvaalensis, protein-gel electrophoresis

\begin{abstract}
Cold acclimation (CA) of 'Midiron' and 'Tifgreen' turf bermudagrasses (Cynodon dactylon L. Pers. x C. transvaalensis Burtt-Davy) induced tolerance to lower freezing temperatures and altered protein synthesis in crowns. $\mathrm{LT}_{50}$ (lethal temperature for $50 \%$ of plants) values were lowered $\approx 5 \mathrm{C}$ after 4 weeks in controlled-environment chambers under CA [8/2C (day/night) cycles with a 10-hour photoperiod] vs. non-CA (28/24C) conditions. LT $_{50}$ values for 'Midiron' plants decreased from -6.5 to $-11.3 \mathrm{C}$ after $\mathrm{CA}$ and from -3.6 to $-8.5 \mathrm{C}$ for 'Tifgreen'. Proteins synthesized by isolated crowns were radiolabeled in vivo for 16 hours with ${ }^{35} S$-methionine and ${ }^{35} S$-cysteine. Sodium dodecyl sulfate polyacrylamide gel electrophoresis and fluorography revealed increased synthesis of several cold-regulated (COR) proteins in CA crowns of both cultivars. Synthesis of intermediate molecular weight (MW) ( 32 to $37 \mathrm{kDa})$ and low-MW (20 to $26 \mathrm{kDa}) \mathrm{COR}$ proteins was greater in 'Midiron' than 'Tifgreen' crowns.
\end{abstract}

Warm-season perennial grasses of the genus Cynodon $(C$. dactylon, C. transvaalensis, and C. dactylon x C. transvaalensis hybrids) are widely used for turf in tropical and subtropical regions throughout the world. Their use also extends into regions of transition between warm- and cool-season species. While substantial differences exist in the winter hardiness of turf bermudagrass cultivars (Fry, 1990), all are subject to freezing injury. Even in relatively mild climatic regions such as the southern United States, bermudagrass turf is severely injured or killed during harsh winters. Tolerance of turf bermudagrass cultivars to freezing, consequently, is a major concern of turfgrass managers in regions subject to these climatic conditions.

Cold acclimation (CA), or cold hardening, is the process by which organisms adjust their metabolism for survival at low temperatures. A dramatic manifestation of $\mathrm{CA}$ is the increased tolerance to freezing demonstrated by many plants after extended exposure to low, nonfreezing temperatures (Thomashow, 1990). Alterations in protein synthesis are associated with CA in a range of plant species (Guy, 1990a; Thomashow, 1990). Although the functions and identities of most proteins synthesized in association with CA remain undetermined, some of these cold-regulated (COR) proteins are likely adaptive and function to enhance plant tolerance to freezing (Guy, 1990b).

Bermudagrass plants are capable of CA. 'Tifgreen' and 'Tifdwarf' bermudagrasses (C. dactylon $\mathrm{x}$ C. transvaalensis) sampled from field plots at Raleigh, N.C., during January and February tolerated lower temperatures than during warmer months

Received for publication 28 June 1993. Accepted for publication 7 Oct. 1993 Approved for publication by the director of the Oklahoma Agricultural Experiment Station (OAES). We gratefully acknowledge the research assistance of Rose Edwards and Glenn Drown and the helpful suggestions of James Ownby and John Cushman. This paper reports cooperative research of the OAES and the U.S. Dept. of Agriculture (USDA)-Agricultural Research Service (ARS), supported in part by grants from the U.S. Golf Association and the Oklahoma Center for the Advancement of Science and Technology. Mention of a trademark or proprietary product does not constitute a guarantee or warranty of a product by the USDA and does not imply its approval to the exclusion of other products that may also be suitable. The cost of publishing this paper was defrayed in part by the payment of page charges. Under postal regulations, this paper therefore must be hereby marked advertisement solely to indicate this fact.

${ }^{1}$ Dept. of Agronomy.

${ }^{2}$ Dept. of Horticulture and Landscape Architecture.

${ }^{3}$ USDA-ARS.
(Davis and Gilbert, 1970). Anderson et al. (1988), using regrowth assays and electrolyte leakage tests, found that field-grown plants of 'Midiron' and 'Tifgreen' bermudagrasses tolerate lower freezing temperatures during December or January than during June. Based on electrolyte leakage from crown tissues, $\mathrm{LT}_{50}$ (lethal temperature for $50 \%$ of plants) values during December or January for 'Midiron' and 'Tifgreen' were -11 and $-7 \mathrm{C}$, respectively. $\mathrm{LT}_{50}$ values for plants sampled during June increased to about -5 and $-3 \mathrm{C}$ for 'Midiron' and 'Tifgreen', respectively. Regrowth assays were also used to estimate $\mathrm{LT}_{50}$ values for both cultivars from February through June. There was close agreement between the electrolyte leakage and regrowth procedures in the estimated $\mathrm{LT}_{50}$ values for plants sampled in March, April, May, or June.

Davis and Gilbert (1970) used disc electrophoresis through polyacrylamide to examine alterations in the composition of soluble proteins isolated from cold-hardened 'Tifdwarf' rhizomes taken either from plants grown in field plots in November or those cold-hardened in a controlled-environment chamber for 15 or 30 days. Several alterations in soluble protein compositions were revealed in samples from field- and chamber-hardened rhizomes when compared to those from nonhardened rhizomes.

Our objective was to characterize alterations in protein synthesis associated with CA of 'Midiron' and 'Tifgreen' turf bermudagrasses as revealed by in vivo radiolabeling and sodium dodecyl sulfate polyacrylamide-gel electrophoresis (SDS-PAGE). Using COR proteins as molecular markers may facilitate screening for freezing tolerance to develop new cultivars with improved cold tolerance.

\section{Materials and Methods}

Plant material and treatments. 'Midiron' and 'Tifgreen' are vegetatively propagated $F_{1}$ hybrids derived from interspecific crosses of tetraploid ( $2 \mathrm{n}=4 \mathrm{x}=36$ chromosomes) C. dactylon $\mathrm{x}$ diploid $(2 \mathrm{n}=2 \mathrm{x}=18$ chromosomes) $C$. transvaalensis plants. One phytomer (crown-stem-root unit) of each cultivar was transplanted from potted turf into 38-mm-diameter $\times$ 204-mm-high cone-tainers (Ray Leach Cone-tainer Nursery, Canby, Ore.). After 6 to 8 weeks under greenhouse conditions, cone-tainers were transferred to controlled-environment chambers (model PGW36; Conviron, Asheville, N.C.). Plants were maintained under 8/2C 
cycles for 28 days with a photosynthetic photon flux of $\approx 300$ $\mu \mathrm{mol} \cdot \mathrm{m}^{-2} \cdot \mathrm{s}^{-1}$ during 10 -h photoperiods for CA and $28 / 24 \mathrm{C}$ cycles as non-CA controls (Anderson et al., 1993). Plants were watered as needed with a dilute fertilizer solution (240 mg 20:20:20 formula per liter distilled water) (Peter's No-Stain; Grace-Sierra, Milpitas, Calif.).

Determining $L T_{50}$ values. $\mathrm{LT}_{50}$ values for plants of four treatment combinations ('Midiron' control, 'Midiron' after CA, 'Tifgreen' control, and 'Tifgreen' after CA) were determined using a regrowth test procedure (Anderson et al., 1993). Plant survival was determined visually as regrowth on a weekly schedule for 8 weeks after applying freezing treatments. Only plants having one or more vigorously growing shoots after 8 weeks were considered viable. $\mathrm{LT}_{50}$ values were estimated by linear interpolation using the percentage of plants surviving at each test temperature.

Collecting and radiolabeling crown tissue in vivo. Crown tissue cores from $\mathrm{CA}$ and control plants were excised and radiolabeled in vivo at 2 to $6 \mathrm{C}$ and 22 to $26 \mathrm{C}$, respectively. Only tissue cores from nonnecrotic crowns lacking chlorophyll but supporting root primordia and green shoots were excised by removing attached roots and shoots and surrounding brown tissues. Excised crowns were washed in distilled water, then radiolabeled in vivo using the procedure of Porter et al. (1989) modified for labeling crown tissues. Incubation buffer [0.35 $\mathrm{ml} 20 \mathrm{~mm}$ tris (pH 7.5) and $5 \mathrm{mg}$ chloramphenicol/ml (an inhibitor of microbial protein synthesis)] were added to $\approx 180 \mathrm{mg}$ crown tissue. $\operatorname{Tran}^{35} S$-label reagent (ICN Biomedicals, Irvine, Calif.), an aqueous solution of ${ }^{35} \mathrm{~S}$-labeled amino acids comprising $\approx 70 \% \mathrm{~L}$-methionine $\left[{ }^{35} S\right], 15 \%$ L-cysteine $\left[{ }^{35} \mathrm{~S}\right]$, and various nonlabeled amino acids, was added at $0.236 \mathrm{mCi}$ to mixtures containing crown tissue from control plants. Tran ${ }^{35} S$ label reagent was added at a $2.5 \mathrm{x}$ rate to acclimated crowns to compensate partially for reduced radioactive amino acid incorporation into proteins of acclimated crowns, relative to controls. For sources of nonradiolabeled protein, $\operatorname{tran}{ }^{35} S$-label reagent was omitted from incubation mixtures of additional crown tissue samples from each treatment combination. Mixtures were vacuum-infiltrated for $30 \mathrm{~min}$. Incubation buffer was removed after $16 \mathrm{~h}$ and crown tissue was stored at $-70 \mathrm{C}$.

Protein extraction, solubilization, quantification, and scintillation counting. Samples of trichloroacetic acid-precipitable, acetone-insoluble material were extracted (Damerval et al., 1986) from $180 \mathrm{mg}$ crown tissue samples that had been stored at $-70 \mathrm{C}$. To solubilize proteins, $10 \mu 1$ solubilization buffer [ $62.5 \mathrm{~mm}$ tris, $\mathrm{pH}$ $6.8,2 \%$ SDS, $10 \%$ glycerol in purified, distilled $\mathrm{H}_{2} \mathrm{O}$ ] was added per milligram dried acetone-insoluble pellet. Solubilization buffer was as described by Laemmli (1970) except without $\beta$ mercaptoethanol ( $\beta-\mathrm{ME}$ ) and bromphenol blue (BPB). Solubilization was for $1 \mathrm{~h}$ at 22 to $26 \mathrm{C}$ with agitation every $15 \mathrm{~min}$. After centrifugation at $12,000 \times g$ for $15 \mathrm{~min}$, supernatants were further clarified by recentrifugation at $12,000 \times g$ for $15 \mathrm{~min}$. Concentrations and radioactivities of proteins in aliquots taken from resulting supernatants were determined using the DC protein assay (BioRad, Richmond, Calif.) and by scintillation-counting proteins remaining adhered to filter-paper disks (Mans and Novelli, 1961), respectively. Solubilization buffer containing $10 \% \beta-\mathrm{ME}$ and $0.0025 \%$ bromphenol blue (BPB) was added $1: 1$ (w/v) to supernatants remaining after protein quantification and scintillation counting to reconstitute a sample buffer with 5\% $\beta$-ME and $0.00125 \%$ BPB for SDS-PAGE. From protein concentration $\left(\mu \mathrm{g} \cdot \mu \mathrm{l}^{-1}\right)$ and specific activity $(\mathrm{kcpm} / \mu \mathrm{g})$ values for each solubilized protein sample, appropriate volumes of ${ }^{35} S$-labeled protein samples, nonradiolabeled protein samples, and solubilization buffer con- taining 5\% $\beta$-ME and $0.00125 \%$ BPB were mixed to prepare samples for each treatment combination containing $32 \mu \mathrm{g}$ protein with equal specific activities in $20-\mu l$ volumes. Solubilized protein samples were stored at $-70 \mathrm{C}$.

Gel electrophoresis, silver staining, and fluorography. For SDS-PAGE, protein samples $(7.5 \mu \mathrm{g}$ and $13.15 \mathrm{kcpm}$ per lane) were electrophoresed through 8 to $10 \mathrm{~mm}$ stacking gels [4\% (w/v) acrylamide $(4.01 \% \mathrm{~T}, 2.74 \% \mathrm{C})$ with $0.1 \%$ (w/v) SDS] over separation gels $[14 \%(\mathrm{w} / \mathrm{v})$ acrylamide $(14 \% \mathrm{~T}, 2.56 \% \mathrm{C})$ with $0.15 \%(\mathrm{w} / \mathrm{v}) \mathrm{SDS}]$ in $16-\mathrm{cm} \times 20-\mathrm{cm} \times 1-\mathrm{mm}$ vertical electrophoresis cells (PROTEAN II xi; Bio-Rad). Radioactive ${ }^{14} \mathrm{C}-\mathrm{me}-$ thylated marker proteins (Amersham, U.K.) of 200.0, 97.4, 69.0, $46.0,30.0$, and $14.3 \mathrm{kDa}$ were electrophoresed to estimate sample protein sizes. The electrophoresis buffer of Laemmli (1970) was used. Gels were silver-stained (Blum et al., 1987), photographed, and stored for several days at $4 \mathrm{C}$ in $50 \%$ methanol. Gels were destained (Kulsar and Prestwich, 1988), impregnated with fluor 2,5-diphenyloxazole (Skinner and Griswold, 1983), dried for fluorography (Porter and Gatschet, 1992), and exposed to preflashed film (X-Omat AR; Kodak, Rochester, N.Y.) at -70C. Gels were exposed for $\approx 9$ days (decay densities in sample lanes were $\approx 7.29$ $\mathrm{kcpm} / \mathrm{cm}^{2}$ ).

Image analysis. Scanned images of silver-stained proteins separated by SDS-PAGE and corresponding fluorographic patterns were analyzed using a densitometer (PDI, Huntington Station, N.Y.) (Krauss et al., 1989). Estimations of protein size (kDa), based on electrophoretic mobilities, and values of band optical density $\times$ height $(\mathrm{OD} \times \mathrm{mm})$ were made using PDI's Quantity One software application. Two fluorographs from each of two gels were scanned. Peak OD values ranged from 0 for transparent regions to 1.47 for saturated images of ${ }^{14} \mathrm{C}$-labeled marker protein bands. Data were reported as band OD $\times$ mm values estimated near centers of lanes, and an increase of at least $100 \%$ was used to indicate $\mathrm{COR}$ protein synthesis. $\mathrm{OD} \times \mathrm{mm}$ values for $\mathrm{COR}$ protein bands of $\approx 14$ to $15 \mathrm{kDa}, 20$ to $26 \mathrm{kDa}$, and 32 to $37 \mathrm{kDa}$ were compared for lanes of 'Midiron' and 'Tifgreen' samples after CA using paired-comparison $t$ tests and analysis of variance (SAS Institute, 1988).

\section{Results and Discussion}

Freezing tolerances. After CA for 28 days, $\mathrm{LT}_{50}$ values for 'Midiron' and 'Tifgreen' were lowered by 5C. Using regrowth assays, $\mathrm{LT}_{50}$ values decreased from -6.5 to $-11.3 \mathrm{C}$ and -3.6 to 8.5C for 'Midiron' and 'Tifgreen' plants, respectively. After CA, 'Midiron' was slightly more tolerant to freezing $\left(2.8 \mathrm{C}\right.$ lower $\left.\mathrm{LT}_{50}\right)$ than 'Tifgreen'. These $\mathrm{LT}_{50}$ values are similar to those reported by Anderson et al. (1988) using electrolyte leakage tests on field-acclimated crown tissues. Other field studies (Fry, 1990) and long-term commercial use patterns also support greater freezing tolerance for 'Midiron' compared to 'Tifgreen'. As expected, $\mathrm{LT}_{50}$ values of CA 'Midiron' and 'Tifgreen' are higher than $\mathrm{LT}_{50}$ values reported for CA cool-season turfgrasses. Rajashekar et al. (1983) reported $\mathrm{LT}_{50}$ values based on electrolyte leakage for cultivars of chewings fescue (Festuca rubra var. commutata Gaud.) from-27.0C for 'Wintergreen' to $-17.5 \mathrm{C}$ for 'Atlanta'. These $\mathrm{LT}_{50}$ values bracketed those for hardened cultivars of perennial rye (Lolium perenne L.), Kentucky bluegrass (Poa pratensis L.), and red fescue (Festuca rubra L.).

$S D S-P A G E$. Proteins of $\approx 34 \mathrm{kDa}$ markedly decreased in 'Midiron' and 'Tifgreen' crowns after CA (Fig. 1). Apparently, proteins of $\approx 34 \mathrm{kDa}$ are degraded more rapidly at low temperatures or are synthesized to a lesser extent in CA than non-CA crowns. 


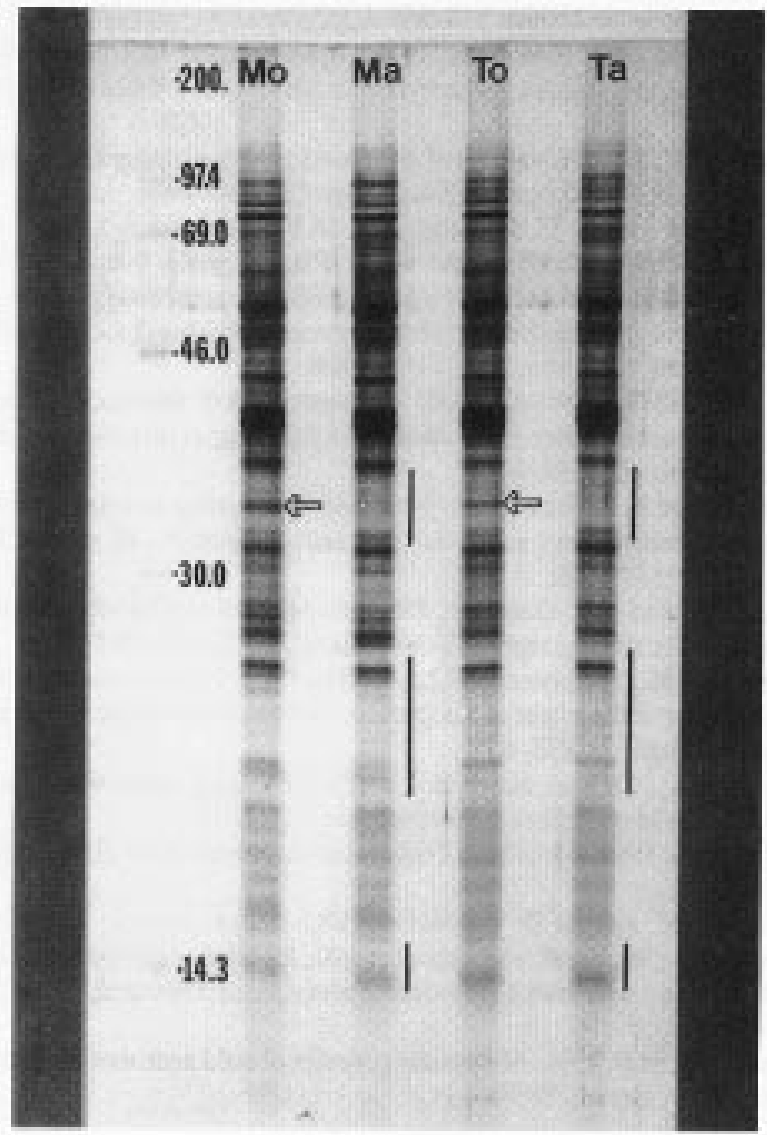

Fig. 1. Silver-stained crown proteins after SDS-PAGE. Left lane: silver-stained ${ }^{14} \mathrm{C}$-labeled marker proteins of 200.0, 97.4, 69.0, 46.0, 30.0, and 14.3 kDa; $\mathrm{Mo}=$ 'Midiron' control; Ma = 'Midiron' after cold acclimation (CA); To = 'Tifgreen' control; Ta $=$ 'Tifgreen' after CA. Protein bands of $\approx 34 \mathrm{kDa}$ from crown protein samples of control 'Midiron' and 'Tifgreen' plants are marked by open arrows. Intermediate molecular weight $(\approx 32$ to $37 \mathrm{kDa})$ and low molecular weight $(\approx 20$ to $26 \mathrm{kDa}$; and $\approx 14$ to $15 \mathrm{kDa}$ ) regions corresponding to those marked in Fig. 2 are indicated by lines to the right of lanes of protein samples from acclimated crowns.

Using Coomassie blue staining, Perras and Sarhan (1989) found decreases in 34-kDa proteins of wheat (Triticum aestivum L.) seedlings after $\mathrm{CA}$ for 10 and 40 days.

Fluorography of radiolabeled proteins revealed alterations in protein synthesis by crowns after CA. Intermediate molecular weight (MW) COR proteins of $\approx 32$ to $37 \mathrm{kDa}$, and low-MW COR proteins of $\approx 20$ to $26 \mathrm{kDa}$ and $\approx 14$ to $15 \mathrm{kDa}$ were synthesized in CA 'Midiron' and 'Tifgreen' crowns (Fig. 2). Peak OD values of all sample protein bands of $\leq 37 \mathrm{kDa}$ were not saturated. COR proteins of $\approx 14$ to $15 \mathrm{kDa}$ were synthesized in greater amounts in 'Tifgreen' than 'Midiron' crowns (Table 1). COR proteins of $\approx 20$ to 26 and 32 to $37 \mathrm{kDa}$, however, were synthesized in greater amounts in 'Midiron' than 'Tifgreen' crowns (Table 1). Differences in levels of COR protein synthesis between CA 'Midiron' and 'Tifgreen' crowns were greatest at 20 to $26 \mathrm{kDa}$.

The low and intermediate MW COR proteins of 'Midiron' and 'Tifgreen' crowns are similar in size to several in vivo radiolabeled COR proteins isolated from CA spinach (Spinacia oleracea L.) seedlings (Guy and Haskell, 1988) and to 15- and 24-kDa COR proteins recovered after in vitro translation of cor RNA sequences from Arabidopsis thaliana L. plants (Lin et al., 1990). Functions of COR proteins in bermudagrass crowns are unknown; however, COR proteins are suspect in cryoprotection (Lin and Thomashow, 1992) and dessication tolerance (Guo et al., 1992).

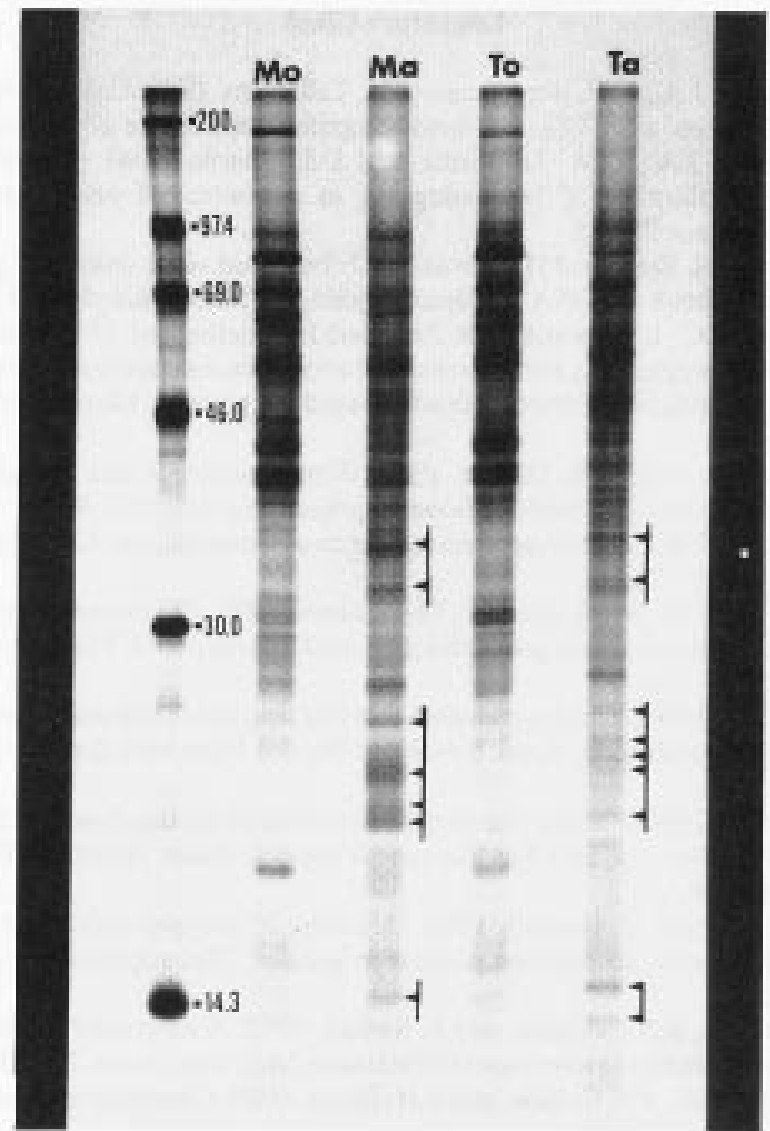

Fig. 2. Fluorograph of ${ }^{35} \mathrm{~S}$-labeled crown proteins after SDS-PAGE. Left lane: ${ }^{14} \mathrm{C}$-labeled marker proteins of 200.0, 97.4, 69.0, 46.0, 30.0, and 14.3 kDa; Mo = 'Midiron' control; Ma = 'Midiron' after cold acclimation (CA); To = 'Tifgreen' control; $\mathrm{Ta}=$ 'Tifgreen' after CA. Intermediate molecular weight $(\approx 32$ to $37 \mathrm{kDa})$ and low molecular weight $(\approx 20$ to $26 \mathrm{kDa}$; and $\approx 14$ to $15 \mathrm{kDa})$ regions corresponding to those of Fig. 1 are indicated by lines to the right of lanes of protein samples from acclimated crowns. Filled arrowheads mark cold-regulated protein bands.

Table 1 . Band optical density $\times$ height $(\mathrm{OD} \times \mathrm{mm})$ averages $( \pm \mathrm{SE})$ of regions of cold-regulated protein bands on fluorographs as revealed by densitometry.

\begin{tabular}{lccc}
\hline \hline & \multicolumn{3}{c}{ Band optical density $\times$ height $(\mathrm{OD} \times \mathrm{mm})$} \\
\cline { 2 - 4 } & \multicolumn{3}{c}{ Molecular weight $(\mathrm{kDa})$} \\
\cline { 2 - 4 } Genotype & $14-15$ & $20-26$ & $32-37$ \\
\hline Midiron & $1.37 \pm 0.06$ & $12.52 \pm 0.18$ & $11.83 \pm 0.45$ \\
Tifgreen & $1.80 \pm 0.08$ & $5.53 \pm 0.39$ & $10.14 \pm 0.70$ \\
Significance & $* *$ & $* * *$ & $*$ \\
\hline
\end{tabular}

*,**,***Significant at $P<0.05,0.01$, or 0.001 , respectively, using either paired-comparison $t$ tests or analysis of variance with fluorographs as replications.

COR proteins may be useful as molecular markers of freezing tolerance. Houde et al. (1992) found that levels of proteins ranging from 14 to $200 \mathrm{kDa}$ that were immunologically related to a $50-\mathrm{kDa}$ COR protein of wheat correlated to levels of freezing tolerance in several CA graminaceous species. Assaying bermudagrass plants for levels of proteins cross-reactive with COR proteins of bermudagrass or other species may help select plants with superior freezing tolerance. The synthesis of low-MW COR proteins $(\approx 20$ to $26 \mathrm{kDa}$ ) may be important for freezing tolerance in bermudagrass. Low-MW COR proteins ( $\approx 20$ to $26 \mathrm{kDa})$ are synthesized during CA in greater amounts in crowns of the more freezing-tolerant 
'Midiron' than in the less freezing-tolerant 'Tifgreen' bermudagrass.

\section{Literature Cited}

Anderson, J.A., M.P. Kenna, and C.M. Taliaferro. 1988. Cold hardiness of 'Midiron' and 'Tifgreen' bermudagrass. HortScience 23:748-750.

Anderson, J.A., C.M. Taliaferro, and D.L. Martin. 1993. Evaluating freeze tolerance of bermudagrass in a controlled environment. HortScience 28:955.

Blum, H., H. Beier, and H.J. Gross. 1987. Improved silver staining of plant proteins, RNA and DNA in polyacrylamide gels. Electrophoresis 8:93-99.

Damerval, C., D. de Vienne, M. Zivy, and H. Thiellement. 1986. Technical improvements in two-dimensional electrophoresis increase the level of genetic variation detected in wheat-seedling proteins. Electrophoresis 7:52-54.

Davis, D.L. and W.B. Gilbert. 1970. Winter hardiness and changes in soluble protein fractions of bermudagrass. Crop Sci. 10:7-9.

Fry, J.D. 1990. Cold temperature tolerance of bermudagrass. Golf Course Mgt. 58:26, 28, 32.

Guo, W., R.W. Ward, and M.F. Thomashow. 1992. Characterization of a cold-regulated wheat gene related to Arabidopsis cor47. Plant Physiol. 100:915-922.

Guy, C.L. 1990a. Cold acclimation and freezing stress tolerance: Role of protein metabolism. Annu. Rev. Plant Physiol. Plant Mol. Biol. 41:187223.

Guy, C.L. 1990b. Molecular mechanisms of cold acclimation, p. 35-61. In: F. Katterman (ed.). Environmental injury to plants. Academic Press, New York.

Guy, C.L. and D. Haskell. 1988. Detection of polypeptides associated with the cold acclimation process in spinach. Electrophoresis 9:787796.

Houde, M., R.S. Dhindsa, and F. Sarhan. 1992. A molecular marker to select for freezing tolerance in Gramineae. Mol. Gen. Genet. 234:43-48. Krauss, M.R., P.J. Collins, and S.H. Blose. 1989. Computer analysed 2D electrophoresis. Nature 337:669-670.

Kulsar, P. and G.D. Prestwich. 1988. Fluorography of tritium-labeled proteins in silver-stained polyacrylamide gels. Anal. Biochem. 170:528531.

Laemmli, U.K. 1970. Cleavage of structural proteins during the assembly of the head of bacteriophage T4. Nature 227:680-685.

Lin, C., W.W. Guo, E. Everson, and M.F. Thomashow. 1990. Cold acclimation in Arabidopsis and wheat. Plant Physiol. 94:1078-1083.

Lin, C. and M.F. Thomashow. 1992. A cold-regulated Arabidopsis gene encodes a polypeptide having potent cryoprotective activity. Biochem. Biophys. Res. Commun. 183:1103-1108.

Mans, R.J. and G.D. Novelli. 1961. Measurement of the incorporation of radioactive amino acids into protein by a filter-paper disk method. Arch. Biochem. Biophys. 94:48-53.

Perras, M. and F. Sarhan. 1989. Synthesis of freezing tolerance proteins in leaves, crown, and roots during cold acclimation of wheat. Plant Physiol. 89:577-585.

Porter, D.R. and M.J. Gatschet. 1992. Simplified drying of polyacrylamide gels for fluorography. Biotechniques 13(3):364-365.

Porter, D.R., H.T. Nguyen, and J.J. Burke. 1989. Chromosomal location of genes controlling heat shock proteins in hexaploid wheat. Theoretical Applied Genet. 78:873-878.

Rajashekar, C., D. Tao, and P.H. Li. 1983. Freezing resistance and cold acclimation in turfgrasses. HortScience 18:91-93.

SAS Institute. 1988. SAS/STAT user's guide. release 6.03. SAS Institute, Cary, N.C.

Skinner, M.K. and M.D. Griswold. 1983. Fluorographic detection of radioactivity in polyacrylamide gels with 2,5-diphenyloxazole in acetic acid and its comparison with existing procedures. Biochem. J. 209:281284.

Thomashow, M.F. 1990. Molecular genetics of cold acclimation in higher plants. Adv. Genet. 28:99-131. 